\title{
CONSEQUENCES OF INTEGRATED USE OF ORGANIC AND INORGANIC FERTILIZERS ON YIELD AND YIELD ELEMENTS OF RICE
}

HEM. C. JOSHI ${ }^{1}$, BABITA JOSHI ${ }^{2}$, S. K. GURU ${ }^{3}$, S. C. SHANKDHAR ${ }^{4}$, A.KUMAR ${ }^{5}$, B. S. MAHAPATRA ${ }^{6}$, M. K. NAUTIYAL ${ }^{7} \&$ PRASHANT SINGH $^{8}$ 1,2,3,4,5 Department of Plant Physiology, College of Basic Sciences and Humanities,

G.B.P.U.A \& T Pantnagar U. S. Nagar Uttrakhand, India

${ }^{6}$ Department of Agronomy, College of agriculture, G.B.P.U.A \& T PantnagarU. S. Nagar, Uttrakhand, India

${ }^{7}$ Department of Genetics \& Plant Breeding, College of agriculture, G.B.P.U.A \& T PantnagarU. S. Nagar, Uttrakhand, India

${ }^{8}$ Department of Biotechnology, Bhimtal Campus, Kumaun University, Nainital Uttarakhand, India

\section{ABSTRACT}

The different concern and issues of contemporary Indian agriculture, gave birth to varied new agriculture ideas of farming like organic farming, natural farming, biodynamic agriculture, and do- nothing farming and ecological agriculture, etc. Integrated use of organic and inorganic fertilizers can improve crop productivity, and encourages soil health and fertility. As perceptive numerous publications, it is concluded that, the application of farmyard manure in combination with three levels of chemical fertilizers [80: 40: 30, 120: 60: 45 and 160: 80: $60 \mathrm{~kg} \mathrm{~N}, \mathrm{P}_{2} \mathrm{O}_{5}$ and $\mathrm{K}_{2} \mathrm{O}$ ha-1, respectively], on yield and yield elements, Rice shows the subsequent information on grain and straw yield, number of tillers, panicle length, filled grains per panicle, 1000-grain weight and nutrient uptake were observed. The results showed that, application of farmyard manure at $10 \mathrm{tha}$ increased grain yield of rice by 25\%, compared to no farmyard manure control. Similar observations were additionally created on straw yield, tiller number, filled grains per panicle, and 1000grain weight. There have been important interactions, between farmyard manure and inorganic fertilizer treatments. The useful effects of application of farmyard manure, were not increased at augmented rates of application of inorganic fertilizers. However, the highest grain yield of rice was obtained, with the application of farmyard manure at $10 \mathrm{tha}$ and inorganic fertilizer at 120: 60: $45 \mathrm{~kg} \mathrm{~N}, \mathrm{P}_{2} \mathrm{O}_{5}$ and $\mathrm{K}_{2} \mathrm{O} \mathrm{ha}^{-1}$. It was ascertained that, the increased grain yield was due mainly to increased nutrient uptake and the number of tillers, filled grains per panicle and 1000-grain weight.

KEYWORDS: Organic Farming, Farmyard Manure, Yield \& Inorganic Fertilizer

Received: Aug 15, 2017; Accepted: Sep 02, 2017; Published: Sep 11, 2017; Paper Id.: IJASROCT201722

\section{INTRODUCTION}

Rice (Oryza sativa L.) is one in all the most important food crops, grown in south Asia. Rice is one of the most important cereal crops of the world, grown in a wide range of climatic zones, to nourish the human population. It is one of the main crops in developing countries and therefore, major food stuff for regarding $35 \%$ of the entire world population. Rice is grown in more than a hundred countries, with a total harvested area of nearly 160 million hectares, producing more than 700 million tons every year. There are primarily four ecosystems, where rice is grown: irrigated, rain-fed lowland, upland, and flood-prone. Each of these environments has its own ideal growing conditions, as, well as limiting factors. It is mostly grown in lowlands, under fully irrigated or rain-fed conditions. Organic materials, particularly farmyard manure and green manures, have traditionally been employed by rice farmers in pre-industrial age. But, with the present day high yielding cultivars, that have higher nutrient needs, the 
utilization of inorganic fertilizers has exaggerated significantly, resulting in decline within the use of organic materials. [1] The impact of increased fertilizer use, in crop production has been large, but ever increasing cost of energy has been an important constraint, for increased use of inorganic fertilizer. [2] Use of organic matter, to meet the nutrient demand of crops would be an inevitable practice in years to come, particularly for resource poor farmers. Moreover, ecological and surrounding issues over the exaggerated and indiscriminate use of inorganic fertilizers, have created an analysis on use of organic materials as a source of nutrient. [3,4] But, the utilization of organic manures alone, might not be enough to meet the enormous nutrient requirements of present day high yielding cultivars. Therefore, an integrated nutrient management in which both organic manures and inorganic fertilizers are used simultaneously, has been suggested as the most effective method to maintain a healthy and sustainable soil system, while increasing crop productivity.[5,6] There is evidence from field research that, high and sustainable yields are possible with integrated use of fertilizers and manure.[7,8] However, it is important to identify the optimum dose of chemical fertilizer, needed for maintaining adequate supply of nutrients for exaggerated yield, and reduced environmental pollution.

Farmyard manure may be a heterogeneous composted organic material, consisting of dung, crop residue, and household sweeping in various stages of decomposition.[9] Farmyard manure is usually accessible and created in farms, and is an important organic resource, for agricultural production in live stock based farming systems in many countries, including semi-arid regions of India.[9] Thus, there is a lot of potential for use of farmyard manure in the fertilizer schedule of rice, and to reduce total dependence on inorganic fertilizers. The present research was therefore, conducted to study the influence of combined application of farmyard manure and different levels of inorganic fertilizer on growth, yield and yield components of irrigated lowland rice.

\section{Effects of Different Fertilizer Treatments on Yield and Yield Attributes of Rice}

Application of farmyard manure, considerably improved number of tillers; number of filling grains, 1000-grain weight, grain yield and straw yield of rice grain and straw yields of rice, were significantly increased by $25 \%$ and $12 \%$, respectively, over no farmyard manure control. Similarly, the number of tillers, number of filling grains, and 1000-grain weights were increased by 12,6 , and $9 \%$, respectively, due to application of farmyard manure. Organic manure plays a vital role in rising soil porosity to air and water stable aggregates. Therefore, application of organic materials such as farmyard manure, significantly improves soil physical properties and nutrient uptake leading to larger growth, yield and yield elements.[10-12] Long-term studies on rice have shown increased yield and yield components, due to application of farmyard manure.[7,8,13] These effects are largely attributed to improved soil organic matter, soil physical, chemical and microbial properties, with application of farmyard manure.[14] There was important influence of various inorganic fertilizer levels, on grain and straw yield, tiller numbers, filled grains per panicle and 1000-grain weight of rice application of $120: 60: 45 \mathrm{~kg} \mathrm{~N}: \mathrm{P}_{2} \mathrm{O}_{5}: \mathrm{K}_{2} \mathrm{O} \mathrm{ha}^{-1}$ produced significantly greater grain yield $\left(3.63 \mathrm{t} \mathrm{ha}^{-1}\right)$, as compared to that obtained with lower fertilizer levels of $\mathrm{N}: \mathrm{P}_{2} \mathrm{O}_{5}: \mathrm{K}_{2} \mathrm{O} \mathrm{ha}{ }^{-1}\left(3.17 \mathrm{t} \mathrm{ha}^{-1}\right)$. However, application of higher fertilizer level of 160: $80: 60$ $\mathrm{N}: \mathrm{P}_{2} \mathrm{O}_{5}: \mathrm{K}_{2} \mathrm{O}$ ha $^{-1}$ produced grain yield of $3.76 \mathrm{t} \mathrm{ha}^{-1}$, which was statistically similar to that obtained with application of 120: 60: $45 \mathrm{~kg} \mathrm{~N}: \mathrm{P}_{2} \mathrm{O}_{5}: \mathrm{K}_{2} \mathrm{O}$ ha $^{-1}$. Similar effects were also observed for straw yield, number of tillers, filled grains per panicle and1000-grain weight. These effects were due to low available $\mathrm{N}$ and $\mathrm{P}$ in the soil. Application of farmyard manure in combination with 120: 60: $45 \mathrm{~kg} \mathrm{~N}: \mathrm{P}_{2} \mathrm{O}_{5}: \mathrm{K}_{2} \mathrm{O}$ ha $^{-1}$, produced an optimum grain yield, when compared to other treatment combinations. Furthermore, the positive effects of farmyard manure were not enhanced with increased rate of inorganic fertilizer application. This is in agreement with other studies that were combined application of organic and 
inorganic fertilizer, which increased productivity of rice. [11, 15]

Few studies have even shown that, organic manures with associate adequate quantity of chemical $\mathrm{N}$ fertilizers may manufacture higher dry matter yield and high $\mathrm{N}$ accumulation, than those of conventional inorganic $\mathrm{N}$ fertilizers treatments.[10,16] A combined use of organic manures and inorganic fertilizers checks nitrogen losses, conserves soil N, by forming organic-mineral complexes and therefore, ensures continuous $\mathrm{N}$ convenience to rice plants and greater yields.[17] Analysis in farmers field on separate and combined application of fertilizers and farmyard manure, has shown

long-term yield benefits, and these effects are attributed for the most part to the upkeep of soil organic matter and microorganism activity.[18] Information on the uptake studies showed that, application of farmyard manure increased the uptake of $\mathrm{N}, \mathrm{P}$, and $\mathrm{K}$ by 20,12 , and $9 \%$, respectively .There were important interactions between organic manure and fertilizer treatment. Most uptake of N, $\mathrm{P}$, and $\mathrm{K}$ was observed at a fertilizer level, of $120: 60: 45 \mathrm{~kg} \mathrm{~N}: \mathrm{P}_{2} \mathrm{O}_{5}: \mathrm{K}_{2} \mathrm{O}$ ha ${ }^{-1}$ in combination with application of farmyard manure. The increase in $\mathrm{P}$ and $\mathrm{K}$ in farmyard manure application treatment, may well be attributed to increase convenience of those nutrients, due to improved soil structure and increased microorganism activity. Analysis has shown that, combined application of farmyard manure and green manure may meet all the nitrogen demand (150 kg fertilizer $\mathrm{N} \mathrm{ha}^{-1)}$ of the high yielding varieties and yielded higher, than the appliance of inorganic fertilizer alone.[10] Long-term effects of integrated nutrient management on productivity of rice-rice cropping system, in both rainy and post-rainy seasons showed that, the employment of inorganic fertilizer (50\%) and farmyard manure or green manure $(50 \%)$, created higher yields than those obtained by application of 100\% of suggested inorganic N.[19] This implies that, judicious use of organic material can produce rice yield, on par with that obtained with inorganic fertilizers.[7,8,12,19] Therefore, application of organic materials have potential of not only improving crop yield, however, additionally reducing dependence on fossil fuel based inorganic fertilizers, thereby, reducing hazards caused by continuous and indiscriminate use of chemical fertilizers. Studies have additionally shown the beneficial effects of green manures, and blue chlorophyte on productivity of rice.[20] Thus, analysis efforts ought to be continued, to check the combined effects of different organic materials such as green manures, legumes, rice straw, compost, sewage sludge, bio-fertilizers (blue green algae and azolla) and inorganic fertilizer, on the productivity of rice in lowland areas.

\section{CONCLUSIONS}

This observation has shown that, application of farmyard manure at $10 \mathrm{t} \mathrm{ha}^{-1}$ increased grain yield of rice by $25 \%$. There have been vital effects of different fertilizer treatments and their interactions with organic manures, generally the useful effects of farmyard manure on yield, yield attributes, and nutrient uptake was less noticeable with increasing levels of inorganic fertilizer. An optimum yield of rice was obtained by application of 120: 60: $45 \mathrm{~kg} \mathrm{~N}^{\mathrm{N}} \mathrm{P}_{2} \mathrm{O}_{5}: \mathrm{K}_{2} \mathrm{O}$ ha ${ }^{-1}$ in combination, with farmyard manure. The highest yield obtained with integrated use of farmyard manure and inorganic fertilizers, was attributed to increased nutrient availability and uptake, resulting in a greater number of tillers, filled grains per panicles and 1000-grain weight.

\section{REFERENCES}

1. Hossain, M.; Singh, V.P. Fertilizer Use in Asian Agriculture: Implications for Sustaining Food Security and the Environment. Nutr. Cycl. Agroecosys. 2000, 57 (2), 155-169.

2. Barker, R.; Herdt, R.W.; Rose, B. The Rice Economy in Asia: Resources for the Future; Government Printing Office: Washington, DC, 1985. 
3. Giller, K.E.; Cadisch, G. Future Benefits from Biological Nitrogen Fixation: An Ecological Approach to Agriculture. Plant Soil 1995, 174 (1-2), 255-277.

4. Ayoub, A.T. Fertilizer and the Environment. Nutr. Cycl. Agro ecosys. 1999, 55 (2), 117-121.

5. Jenssen, B.H. Integrated Nutrient Management: The Use of Organic and Mineral Fertilizer. In The Role of Plant Nutrients for Sustainable Food Crop Production in Sub-Saharan Africa; Van Reuler, H., Prins, W.H., Eds.; VKP: Ledschendam, The Netherlands, 1993, 89-105.

6. Palm, C. A.; Myers, R.J.K.; Nandwa, S.M. Combined Use of Organic and Inorganic Nutrient Sources for Soil Fertility Maintenance and Replenishment. In Replenishing Soil Fertility in Africa; Buresh, R.J., Sanchez, P.A., Calhoun, E., Eds.; Soil Science Society of America: Madison, WI, 1997; Spec. Publ. No. 51, 193-217.

7. Raman, K.R.; Singh, M.P.; Singh, R.O.; Singh, U.S.P. Long-term Effects of Inorganic and Organo-Inorganic Nutrient Supply System on Yield Trends of Rice-Wheat Cropping System. J. Appl. Biol. 1996, 6 (1-2), 56-58.

8. Singh, N.P.; Sachan, R.S.; Pandey, P.C.; Bisht, R.S. Effects of Decade Long Fertilizer and Manure Application on Soil Fertility and Productivity of Rice-Wheat System in a Mollisol. J. Indian Soc. Soil Sci. 1999, 47 (1), 72-80.

9. Motavalli, P.P.; Singh, R.P.; Anders, M.M. Perception and Management of Farmyard Manure in the Semiarid Tropics of India. Agr. Syst. 1994, 46 (2), 189-204

10. Singh, Y.; Singh, B.; Khera, T.S.; Meelu, O.P. Integrated Management of Green Manure, Farmyard Manure, and Nitrogen Fertilizer in a Rice-Wheat Rotation in Northeastern India. Arid Soil Res. Rehab. 1994, 8 (2), 199-205.

11. Pandey, N.; Sarawgi, A.K.; Rastogi, N.K.; Tripathi, R.S. Effect of Farmyard Manure and Chemical N Fertilizer on Grain Yield and Quality of Scented Rice (Oryza sativa) Varieties. Indian J. Agr. Sci. 1999, 69 (9), 621-623.

12. Mondal, S.S.; Chettri, M. Integrated Nutrient Management for Sustaining Productivity and Fertility Under Rice (Oryza sativa) -Based Cropping System. Indian J. Agr. Sci. 1998, 68 (7), 337-340.

13. Nambiar, K.K.M.; Abrol, I.P. Long-term Fertilizer Experiments in India: An overview. Fert. News 1989, 34, 11-20.

14. Gaur, A.C.; Neelakantan, S.; Dargan, K.S. Organic Manures; Indian Council of Agricultural Research: New Delhi, India, 1984.

15. Ghosh, A.; Sharma, A.R. Effect of Combined Used of Organic Manure and Nitrogen Fertilizer on the Performance of Rice under Flood-Prone Lowland Conditions. J. Agric. Sci. (Cambridge) 1999, 132 (4), 461-465.

16. Chung, R.S.; Wang, C.H.; Wang, C.W.; Wang, Y.P. Influence of Organic Matter and Inorganic Fertilizer on the Growth and Nitrogen Accumulation of Corn Plants. J. Plant Nutr. 2000, 23 (3), 297-311.

17. Sharma, A.R.; Mittra, B.N. Effect of Combinations of Organic Materials and Nitrogen-Fertilizers on Growth, Yield and Nitrogen Uptake of Rice. J. Agr. Sci. (Cambridge) 1988, 111 (3), 495-501.

18. 18. Ghoshal, N.; Singh, K.P. Effects of Farmyard Manure and Inorganic Fertilizer on the dynamics of Soil Microbial Biomass in a Tropical Dryl and Agro ecosystem. Biol. Fert. Soils 1995, 19 (2-3), 231-238.

19. Katyal, V.; Gangwar, B. Long-term Effect of Integrated Nutrient Management on Crop Productivity of rice (Oryza sativa) Rice System. Indian J. Agr. Sci. 2000, 70 (2), 110-113.

20. Meelu, O.P.; Jerath, N. Bio-Fertilizers and Their Potential in Crop Production. In Changing Scenario of Our Environment; Dhaliwal, G.S., Hansra, B.S., Eds.; Punjab Agricultural University: Ludhiana, India, 1992; 281-286. 